\title{
VASOS COMUNICANTES DO MODERNO: OCTAVIO PAZ E O SURREALISMO
}

Priscila Ribeiro Dorella*

Resumo: O poeta e ensaísta mexicano Octavio Paz (1914-1998) teve, como se sabe, diversas influencias intelectuais, artísticas e políticas. Certamente, o surrealismo é uma das mais importantes, embora seja uma de suas "afinidades eletivas" menos estudadas. As relações entre Paz e os surrealistas, como André Breton e Luis Buñuel, se estabeleceram a partir das manifestações artísticas, mas foram aprofundadas no compartilhar de uma percepção ética e moral da sociedade. Por meio de uma análise do seu envolvimento com o surrealismo, este artigo busca discutir, em certa medida, como este movimento subversivo está presente na obra e na vida do poeta em questão.

Palavras-chave: André Breton. Octavio Paz. Marxismo. Modernidade. Surrealismo.

\begin{abstract}
The Mexican poet and essayist Octavio Paz (1914-1998) had, as it is known, various intellectual, artistic and political influences. Undoubtedly, the surrealism is one of his most important influence, although it is also one of his less studied "elective affinities". The relationship between Paz and the Surrealists, such as Andre Breton and Luis Brunel, was settled by the artistic manifestation, but was improved by a common share of an ethical and moral perception of the society. Analysing his involvement with the surrealism, this article attempts to discuss, to some extend, how this subversive movement is presented in his work and life.
\end{abstract}

Keywords: André Breton. Octavio Paz. Marxism. Modernism. Surrealism.

* Doutoranda no Programa de Pós-Graduação em História da Universidade Federal de Minas Gerais, com apoio da FAPEMIG. E-mail: priscila.dorella@yahoo.com.br 
O poeta e ensaísta mexicano Octavio Paz (1914-1998) nunca aderiu integralmente ao grupo surrealista. Mas algumas de suas poesias como Mariposa de Obsidiana são traçados denominados, por ele, de surrealistas e alguns de seus ensaios são manifestações em homenagens aos principais representantes desse movimento, como André Breton, Juan Miró, Luis Buñuel, Paul Éluard e Benjamin Péret. No seu ensaio, sobre Breton, em razão de sua morte, no ano de 1966 - André Breton ou a busca do começo ${ }^{1}$, afirmou, por exemplo, que em muitas ocasiões escreveu como se sustentasse um diálogo silencioso com "o pai do surrealismo", onde coexistiam réplica, resposta, coincidência, divergência e homenagem. Diferenças evidentes existiam entre Paz e Breton: o primeiro se tornou um crítico fervoroso da esquerda e o outro um trotskista incorrigível. O que eles partilhavam é, para além de uma poética subversiva que se propõe a superar a dualidade entre "arte" e "ação", o espírito orgulhoso de revolta e de insubmissão, uma mútua admiração. Paz o considerava um grande revolucionário herdeiro do romantismo, enquanto Breton reconhecia em Paz o poeta de língua espanhola mais comovente.

É importante dizer que a relação de Paz com o surrealismo foi parte de um processo de transformação que resultou de atitudes iniciais receosas a um interesse profundo sobre o tema, que o conduziu, segundo assinalou o crítico literário Eduardo Becerra $^{2}$, a um destacado papel como revitalizador do movimento. Encantamento - é um termo possível para explicar essa mudança dos sentimentos do poeta quando de sua descoberta do surrealismo nos anos de 1930. Em entrevista ao escritor colombiano Álvaro Mutis ${ }^{3}$, nos anos de 1980, Paz contou que foi durante esses anos que começou a ler textos surrealistas, em revistas como Contemporáneos, Sur, Revista de Occidente e La Gazeta Literária, onde apareciam poemas de Paul Éluard, Breton e Philippe Soupault. A "revelação" em relação a Breton veio, um tempo depois, quando leu o capítulo “O Castelo Estrelado" de seu livro O amor louco, na revista Argentina Sur, em que este divagava sobre o amor, o considerando uma das grandes revoluções subversivas da modernidade. Isso foi para Paz uma enorme novidade, pois em plena crença da razão e do progresso, os surrealistas defendiam, justamente, a poesia e o amor como um dos únicos capazes de transformar a realidade e de dizer verdades não ditas. 
Mais tarde, escreveu sobre esse fascínio ao tratar da importância dos movimentos de vanguarda, como o surrealismo, e suas semelhanças com o romantismo, no livro Los hijos del limo - del romantismo a la vanguardia, de 1974. Para Paz, tanto o romantismo quanto as vanguardas foram movimentos juvenis, rebeliões contra a razão, tentativas de destruir a realidade visível para encontrar ou inventar outra - mágica, sobrenatural, super real, que, provocadas pelas transformações políticas, como a Revolução Francesa e a Revolução Russa, pretenderam unir a vida e a arte. ${ }^{4}$ Porém, ainda nos anos de 1930, Paz era um poeta militante de esquerda, que começava a lidar, por meio dessas e outras influências, com um conflito que, para ele, se agravaria com o tempo: as possibilidades de compatibilidade entre as suas perspectivas estéticas e poéticas com as suas simpatias pelo comunismo, nesse momento, muito vinculadas às experiências radicais oriundas da Revolução Russa. O poeta, por apreciar, com afinco, a liberdade de expressão e de imaginação, condenava, cada vez mais, com o passar dos anos, o autoritarismo revolucionário.

A política não era a nossa única paixão. Tanto ou mais nos atraíam a literatura, as artes e a filosofia. Para mim e para outros poucos entre meus amigos, a poesia se converteu, não exatamente em uma religião pública, mas em um culto esotérico oscilante entre as catacumbas e o sótão dos conspiradores. Eu não encontrava oposição entre a poesia e a revolução: as duas eram facetas do mesmo movimento, duas asas da mesma paixão. Esta crença me uniria mais tarde aos surrealistas. ${ }^{5}$

No México, ao final dos anos de 1930 e início de 1940, Paz passa expressar publicamente tanto a ideia da poesia como um meio de comunicação absolutamente transformador, quanto os seus questionamentos políticos em relação às ideias autoritárias por meio de publicações e debates públicos polêmicos, o que o levou, aos poucos, a se distanciar de muitos dos seus companheiros de esquerda como Vicente Lombardo e José Revoltas, e se aproximar de alguns anarquistas e surrealistas como Victor Serge e Benjamin Péret. Por outro lado, sabemos que muitas figuras pertencentes ao surrealismo se declaravam comunistas. Inicialmente, não havia uma contradição tão evidente, ou, como ele mesmo notava: "era uma contradição da época". 6

De acordo com Michael Lowy, em seu livro A Estrela da manhã: surrealismo e marxismo, com frequência, reduziu-se o surrealismo a pinturas, esculturas ou coletâneas de poemas, mas o surrealismo é também um estado de espírito e uma filosofia política que teve forte ligação com o marxismo. No Segundo Manifesto de Breton (1929), é possível observar uma simpatia pelas 
ideias comunistas. Em 1927, muitos surrealistas se aliam ao Partido Comunista Francês e, em 1935, outros tantos rompem com o stalinismo por ocasião do Congresso em Defesa da Cultura e se vinculam ao trotskismo. Na Cidade do México, em 1938, por exemplo, Breton se uniu a Trotsky com o objetivo de lutar pela independência da arte e pela revolução socialista. Chegaram a redigir um manifesto, após muitas discussões, em conjunto com o pintor muralista Diego Rivera, manifesto este denominado "A independência da arte para a revolução. A revolução para a independência definitiva da arte". Publicado em nome da Federação Internacional da Arte Revolucionária e Independente (F.I.A.R.I.), em oposição à chamada "arte engajada" a serviço do Estado, imposta pelo stalinismo através da Associação Russa de Escritores Proletários (A.R.E.P.).

O lugar de convergência mais profundo entre o surrealismo e o comunismo era, como assinalou Lowy, "o pessimismo revolucionário" que se traduz na convicção de que não se pode viver como um ser humano digno desse nome sem combater com persistência e vontade inabalável a ordem estabelecida. ${ }^{7}$ É possível afirmar que quando muitos surrealistas retomaram a sua irrevogável tentativa subversiva de reencantamento do mundo através da re-valorização da revolta, da utopia, da liberdade, da imaginação, da poesia e do amor louco, e a Revolução Russa, mostrou, como nunca, uma face autoritária, determinista, intolerante e cruel, principalmente, através das denúncias de existência dos campos de concentração na URSS stalinista, foi que surrealistas, como Luis Buñuel, selaram suas incompatibilidades com o comunismo. Como assinalou o cineasta espanhol, em sua autobiografia:

Conservei as minhas simpatias pelo partido comunista até o final do anos cinquenta. Depois, me afastei cada vez mais dele. $\mathrm{O}$ fanatismo me repugna, onde quer que eu o encontre. Todas as religiões encontraram verdade. O marxismo, também. Nos anos trinta, por exemplo, os doutrinários marxistas não suportavam que se falasse em subconsciente, nas tendências psicológicas do indivíduo. Tudo deveria obedecer aos mecanismos socio-econômicos, o qual me parecia absurdo. Se esquecia a outra metade do homem. ${ }^{8}$

Ainda sim, é relevante lembrar que Breton foi um dos surrealistas fiéis à memória de Trotsky. De acordo com o cientista político Yvon Grenier, muitos intelectuais e artistas dos anos de 1930 e 1940 viam Trotsky com romantismo, uma vez que ele era um revolucionário - "un poète maldit in actu” e um sensível apreciador das diversas expressões artísticas. ${ }^{9}$ A oportunidade de Paz conviver com os surrealistas e, até mesmo, com os anarquistas frutificou devido ao fato do governo Cárdenas (1934-1940) ter concedido asilo político aos exilados 
da Guerra Civil Espanhola (1937-1939), e também ter possibilitado muitos artistas e intelectuais franceses se refugiarem, no México, durante a Segunda Guerra Mundial. Estes refugiados políticos acabaram por desenvolver um considerável interesse pela cultura pré-colombiana e mexicana, o que, por outro lado, contribuiu para diversificar o cenário artístico e intelectual mexicano daquela época, muito voltado, ainda, segundo o historiador Enrique Krauze, ao nacionalismo, e a buscar por assimilar a vasta experiência bélica, social, política e cultural que representou a Revolução Mexicana (1910-1917). ${ }^{10}$ Como pontuou o poeta:

Fui colaborador de um diário de trabalhadores à esquerda: $E l$ Popular, mas o pacto entre Stalin e Hitler me desconcertou e me doeu. Decidi separar-me do periódico e me afastei dos meus amigos comunistas. Minhas relações com eles pioraram a luz do assassinato de Trotsky [...] eu me senti cercado e acurralado. Então conheci a Victor Serge, a Benjamin Péret e a outros escritores revolucionários desterrados no México. Estas novas amizades romperam um pouco o meu isolamento. [...] As conversações com os refugiados europeus, além disso, me revelaram as minhas limitações e as minhas lacunas. Aqueles amigos me fizeram descobrir outros mundos. E, sobretudo, o que significa o pensamento crítico. Como um bom hispano-americano, eu conhecia a rebelião; a indignação pessoal (não a crítica). A eles eu devo o fato de saber que a paixão deve ser lúcida. ${ }^{11}$

Os anarquistas e os surrealistas apresentaram Paz ao pensamento crítico, como é possível observar na citação anterior. Esse fato, segundo ele, o salvou dos fanatismos tanto literário quanto político: “Aprendi que a política não é só ação, mas participação. Talvez, me disse, não se trata de transformar os homens, e sim de acompanhá-los e ser um deles."12 Segundo a jornalista mexicana Elena Poniatowska, a personalidade do anarquista Victor Serge, por exemplo, chamou a atenção de Paz por ter reconhecido nele qualidades opostas que se complementavam, como a intransigência moral e intelectual com a tolerância e a compaixão. Escreveu muito, posteriormente, sobre figuras que valorizavam o pensamento crítico, como os poetas Xavier Villarrutia, Sor Juana Inés de la Cruz, López Velarde e Breton, tanto quanto sobre a necessidade de autonomia da arte em relação à política.

Foi longo o caminho percorrido até Paz conhecer Breton e passar a defender o surrealismo. Paz não conheceu Breton quando este visitou o México, ao final dos anos de 1930. Apesar de ter lido, com fascinação, alguns de seus livros. O poeta e amigo José Cuesta ${ }^{13}$ do grupo modernista mexicano 
Contemporáneos chegou a insistir para que os dois se conhecessem, mas Paz não quis. Não se aproximou dele porque acreditava que suas críticas a III Internacional (Komintern) podiam dar razões aos inimigos nazi-fascistas e prejudicar os republicanos da Guerra Civil Espanhola (1936-1939). Segundo Becerra, nem a Exposição Internacional Surrealista promovida por Breton, em 1940, na Cidade do México, gerou uma reação entusiasmada do poeta.

Não obstante, em 1937, Paz viajou a Europa com a Liga Escritores e Artistas Revolucionários (LEAR) contra o fascismo. Lá, em plena Guerra Civil Espanhola, além conhecer renomados intelectuais como Pablo Neruda e Luis Buñuel, testemunhou a intolerância dos stalinistas em relação aos trotskistas e anarquistas e passou a rever os seus posicionamentos políticos. A postura intransigente dos stalinistas foi fundamental para o poeta compreender a necessidade da crítica como bússola moral para a vida.

Minhas primeiras dúvidas começaram na Espanha devido aos métodos abomináveis que empregaram os comunistas para combater a oposição de esquerda, ou seja, os anarquistas, o POUM e os trotskistas. Depois, a disputa entre os stalinistas e os trotskistas me abriu os olhos sobre muitas coisas. Fiz minha as críticas ao trotskismo ao stalinismo. Posteriormente, assumi as críticas ao trotskismo de muita gente que não era trotskista, como Victor Serge. Minha grande ruptura ocorreu no começo da década dos nos cinquenta, quando descobri a existência dos campos de concentração da União Soviética. ${ }^{14}$

Como é possível notar, Paz reviu as suas posições políticas e concluiu que estava equivocado em questionar as críticas de Breton ao totalitarismo stalinista. Mais tarde, terminou por endossar em suas memórias a visão amarga de Breton sobre essa temática.

\begin{abstract}
A história dirá se os que reivindicam hoje o monopólio da transformação social do mundo trabalham para a libertação do homem ou o entregam a uma escravidão ainda pior. O surrealismo como movimento definido e organizado em vista de uma vontade de emancipação mais ampla, não pode encontrar um ponto de inserção nesse sistema... ${ }^{15}$
\end{abstract}

Apesar de Breton denunciar a falta de liberdade do regime stalinista, alguns intelectuais e artistas que apoiaram Stalin não deixaram de ser influenciados pelo surrealismo. O poeta chileno Pablo Neruda é um exemplo, pois embora tenha se tornado um stalinista quando muitos surrealistas tinham 
selado sua incompatibilidade com o Stálin, ele escreveu diversos poemas sob forte inspiração surrealista, como Caballo verde para poesia. Mesmo assim, Paz considerou execrável a postura política de Neruda, e de alguns poucos surrealistas como Aragon. Observe o trecho abaixo, publicado no seu livro El ogro filantrópico, de 1978.

Quando penso em Aragon, Éluard, Neruda e outros famosos poetas e escritores stalinistas, sinto o calafrio que me da a leitura de certas passagens do inferno. Começaram de boa fé, sem dúvida: Como fechar os olhos diante dos horrores do capitalismo e diante do desastre do imperialismo na Ásia e na África e na nossa América? Experimentaram um impulso generoso de indignação diante do mal e de solidariedade diante das vítimas. Mas insensivelmente, de compromisso em compromisso, se viram envolvidos em uma malha de mentiras, falsidades, enganos e preconceitos até perderem a alma. Transformaram-se, literalmente, em desalmados. Pode parecer exagerado: Dante e seus castigos por suas opiniões políticas equivocadas? E quem crê hoje na alma? Acrescento que nossas opiniões nessa matéria não foram menos erradas ou falhas do que nossa faculdade de julgar. Foi um pecado, no antigo sentido religioso da palavra: algo que afeta o ser inteiro. ${ }^{16}$

O debate em relação ao engajamento político, a função do intelectual na sociedade e sua relação com o poder era, sob muitos aspectos, uma questão moral que permeava a vida social daqueles tempos de fortes tensões ideológicas, em que a consolidação de Stalin no poder, a Guerra Civil Espanhola, a ameaça mundial do fascismo, a Segunda Guerra Mundial e a afirmação dos EUA como potência imperialista, provocaram transformações substantivas no cenário mundial.

Em 1946, oito anos depois de Breton ter estado no México, lugar, para ele, de eleição dos surrealistas ${ }^{17}$, Paz é convidado, com a ajuda de seu amigo, o poeta José Gorostiza, a trabalhar, na França, como Terceiro Secretário da embaixada mexicana. Naquela época, a França continuava a ser a "pátria intelectual" dos latino-americanos. Lá, Paz conviveu e conheceu célebres intelectuais como: Julio Cortázar, Josep Palau, Rufino Tamayo, Adolfo Bioy Casares, Silvia Ocampo, Albert Camus, Roger Callois, Kostas Papaionnou, Raymond Aron e Cornelius Castoriadis. É precisamente nesse período que Paz foi apresentado a Breton através do seu amigo surrealista Péret, especialmente quando o movimento, segundo ele, "havia deixado de ser uma chama". ${ }^{18}$ Entretanto, não se importava porque acreditava que eles haviam dado, a ele, 
a consciência clara da importância da imaginação e da palavra como força de liberação do homem.

É possível dizer que existiram várias gerações de surrealistas com formações e perspectivas distintas que alimentaram o movimento durante muitos anos. Como afirmou Buñuel, foi uma espécie de chamada aqui e ali, nos Estados Unidos, na Alemanha, na França, na América Latina etc, de pessoas que utilizaram uma expressão intuitiva e irracional. Certamente, qualquer um poderia aderir formalmente à proposta subversiva do movimento como também ser expulso dele pelo seu fundador - Breton. Segundo o cineasta espanhol:

A maioria daqueles revolucionários - igual aos senhores com quem eu convivia em Madrid - era de boa familia. Burgueses que se rebelaram contra a burguesía. Este era o meu caso. A isso se somava em mim certo instinto negativo, destrutor, que sempre senti com mais força que toda tendência criadora. Por exemplo, sempre me pareceu mais atrativa a ideia de incendiar um museu que a de abrir um centro cultural ou fundar um hospital. ${ }^{19}$

Nesse tempo que Paz viveu na França, o poeta frequentou tanto os cafés La Place Blanche e Promenoir de Venice, uns dos principais lugares de predileção dos surrealistas em Paris, localizados em uma zona marginal da capital francesa, quanto também a casa de Breton. O poeta contou que ele morava em um apartamento pequeno, mas que isso não o impedia de colecionar objetos de arte pré-colombiana por todos os lados. Sua admiração pelo México o fez um dos primeiros e principais divulgadores de artistas mexicanos na Europa, que nutriam pontos de contato com o surrealismo, como foi o caso da pintora Frida Khalo (1907-1954) e do fotógrafo Manuel Álvarez Bravo (1902-2002).

À medida que Paz se aproximou dos surrealistas, ele compreendeu melhor que a razão do profundo interesse de muitos deles pelo México não era dada simplesmente pelo fato do país representar, para eles, o primitivo, o exótico, o desconhecido e a distância em relação à Europa, mas também por eles terem construído essas imagens pitorescas sobre o México a partir das leituras que fizeram de artistas e intelectuais europeus advindos de outras gerações e movimentos. O poeta afirmou, por exemplo, que Breton leu na sua infância os romances de aventura do francês Gabriel Ferry, escritor de livros como Capitaine Don Blas et les jarochos, scenes de la vie mexicaine, 1848 Impressions de voyages et aventures dans le Mexique, la Haute Californie et les régions de l'or, 1851 Costal l'Indien; roman historique. Scènes de la guerre de l'indépendance du Mexique, 1852 - Scènes de la vie sauvage au Mexique, 1879, que muito contribuiu para a sua visão mítica a respeito do México. 
Por outro lado, antes mesmo de conhecer os surrealistas, Paz já lia os poetas modernos que os surrealistas liam, como Apollianaire, Lautréamont, Rimbaud, Nerval, e os poetas espanhóis tocados pelo surrealismo, como Neruda, Cernuda, Prados, García Lorca e Alberti. Assim, é difícil definir o grau de influência desses pensadores sobre Paz, uma vez que certas ideias políticas e artísticas, tratadas pelo poeta, estavam também dispersas na atmosfera intelectual daquele tempo. Apesar dele apontar, em seus escritos e entrevistas, algumas das origens intelectuais de sua obra reverenciada, e afirmar as suas afinidades com Breton e Buñuel, sabemos que a eleição de seus precursores, expressa em textos ensaísticos, presta-se, também, diversas vezes, a armadilhas analíticas de imprecisão e anacronismo.

Segundo o historiador mexicano Froylán Enciso, o período que Paz viveu na França, de 1946 a 1951, determinou por muitos anos as suas opiniões políticas, principalmente as suas críticas em relação à esquerda stalinista, e a sua defesa em favor do sistema político democrático, como também inaugurou uma fase de reconhecimento e produtividade ao publicar, por exemplo, o ensaio O labirinto da Solidão (1950) e o livro de poemas Águia ou sol? (1951). O poeta teve algumas colaborações consideráveis ao grupo surrealista como o já mencionado poema Mariposa Obsidiana, publicado para a Revista de Meio Século do Surrealismo, em 1950, e a sua campanha em Cannes em prol do filme de Buñuel - Los Olvidados, de 1951.

O poema trata do maravilhoso, na civilização Asteca - a divindade Chichimeca Noturna, como também da Virgem de Guadalupe. É um poema bastante religioso por uma parte e bastante blasfemo por outra. Esse aspecto herege, segundo o poeta, irritou os marxista-leninistas, pois o poema destrói toda "a ideologia corset infame" ao dar asas à imaginação. ${ }^{20}$ Segue abaixo, uma pequena estrofe:

Me pegaram suavemente e me depositaram no átrio da catedral. Me fizeram cinza tal que muitos me confundiram com um monócito de poeira. Sim, eu mesma, a mãe de padernal, eu grávida do raio, sou agora a caneta que abandona o pássaro no espinheiro. Dançando, os peitos no alto e girando, girando até ficar parada, então começava a destacar folhas, flores e frutos. No meu ventre batia a águia. ${ }^{21}$

A proposta poética de Breton, assim como a de muitos poetas românticos, o colocou em contato com a ideia de que as contradições mais radicais da existência - a vida e a morte; o real e o imaginário; o passado e o futuro; o comunicável e o incomunicável - poderiam ser percebidos em sua íntima 
unidade. Nesse caso, a Mariposa Obsidiana (material que é representação da alma humana e, ao mesmo tempo, utilizado para fabricar as facas do sacrifício), símbolo dual da vida e da morte, ao passar, na sua obra, de deusa generosa da vida, mãe do mundo fundida com a natureza, à imagem diminuída e terna encerrada entre os muros das catedrais é reveladora do hibridismo indígena e espanhol, latente na própria cultura mexicana.

Em prol do filme de Buñuel - Los Olvidados, Paz promoveu uma forte campanha de divulgação dessa obra, que representou, com dureza, aspectos problemáticos da Cidade do México. O impacto do filme, na França, foi o de provocar muitos debates. O Le Monde o colocou nas nuvens e L'Humanité o considerou abaixo da crítica. Isso ocorreu porque, segundo Paz, eram os anos do "realismo socialista" em que era comum se exaltar como valor central as obras de arte de sentido positivo. Já a recepção do filme no México foi péssima, principalmente porque os nacionalistas acreditavam que aquelas imagens maculavam o país. No entanto, Paz defendeu o filme no texto El poeta Buñuel que, junto com uma poesia de Péret, foi repartido em folhas soltas na entrada do cinema, no festival de Cannes. Para ele, a obra de Buñuel - Los Olvidados - é uma inquestionável obra de arte, pois apresenta, de maneira única, uma temática comum a toda a humanidade - a miséria.

O embaixador mexicano Torres Bodet rejeitou a aproximação de Paz com os surrealistas, principalmente a sua campanha em favor do filme de Buñuel - Los Olvidados que, segundo Bodet, comprometeu a imagem internacional do México. ${ }^{22}$ Por outro lado, o problema, segundo Paz, seria a conduta desses intelectuais e artistas, como Bodet, que, em nome do Estado ou da memória da Revolução Mexicana, desconsideravam ou, até mesmo, excluíam a alteridade e a autocrítica como possibilidade para a constituição de uma nação moderna. ${ }^{23}$ Em carta a Poniatowska, no ano de 1967, Paz esclareceu, uma vez mais, sua visão sobre essa questão:

O nacionalismo foi uma invenção europeia e o cosmopolitismo também, ou seja, os dois são atitudes que refletem o que passa nos outros lados. O importante é nem extasiar-se diante do "Mexiquitito" e, muito menos, lutar contra ele. O importante é escrever obras que, ao menos, sejam válidas na língua espanhola nesse momento. Pelo menos! E se tudo der certo, que sejam realmente universais. Mas para criar obras universais não é indispensável seguir o último grito de Paris ou de Londres. ${ }^{24}$

O conflito vivido, entre Paz e o embaixador mexicano Torres Bodet, além de evidenciar suas resistências ao discurso intelectual ufanista, foi uma 
das causas de sua transferência da França para o México, como funcionário da embaixada mexicana. Ainda sim, Buñuel reconheceu o esforço de Paz, e pontuou em suas memórias:

Tudo mudou depois do festival de Cannes em que o poeta Octavio Paz - homem do qual Breton me falou pela primeira vez e a quem admiro dede muito tempo distribuía pessoalmente na porta da sala um artigo que havia escrito, ou melhor, sem dúvida, que havia lido, um artigo belíssimo. O filme conheceu um grande êxito, obteve críticas maravilhosas e recebeu o Prêmio de Direção. [...] Depois do êxito europeu, me vi absorto do lado mexicano. Cessaram os insultos, e o filme reestreou em uma boa sala do México, aonde permaneceu dois meses. ${ }^{25}$

No México, Paz continuou a levantar a bandeira do movimento surrealista diante dos nacionalistas, que estavam ávidos por "enterrá-lo". A sua conferência "Los grandes temas de nuestro siglo"26, realizada em 1954, no teatro Bellas Artes, com um público de cerca de 500 pessoas, foi uma expressiva iniciativa de apresentar aos mexicanos um dos "maiores movimentos do século XX". O surrealismo não foi, de acordo com ele, uma escola de delírio, mas de razão crítica que o México deveria saber apreciar, pois no auge da Guerra Fria (1954-1964), muitos membros do movimento conseguiram, como poucos artistas e intelectuais do período, se oporem, com um olhar crítico, à propaganda hegemônica, tanto de Moscou quanto de Washington. ${ }^{27}$

É importante dizer que, ao longo de sua trajetória, Paz procurou pensar o México para além de suas fronteiras nacionais, contribuir para a modernização da cultura mexicana e se tornar um intermediário entre a América Hispânica e a modernidade ocidental. Em parte, isto explica o seu crescente fascínio pelo movimento surrealista, apesar de ser acompanhado também por algumas discordâncias, pois rejeitava a defesa de alguns surrealistas pela escrita automática, que na sua visão era uma insistência inalcançável, e a adesão cega de tantos outros surrealistas pelo comunismo. Ainda sim, não se pode deixar de constatar uma profunda "afinidade eletiva" entre o seu empenho como crítico da modernidade e as ideias e atitudes de Breton e seus amigos.

Seguramente, a sua percepção sobre o movimento sensibilizou a muitos artistas e intelectuais mexicanos que já buscavam por Paz e sua admirável versatilidade intelectual, antes mesmo dele se consagrar com o Prêmio Nobel de Literatura, em 1990. O poeta Juan José Arreola nomeava o poeta de "bezerro de ouro", porque, em sua visão, muitos se curvavam diante dele, no México. Poniatowska citou, em suas memórias sobre o poeta, algumas figuras públicas 
mexicanas que eram atraídas por ele: Carlos Monsiváis, José Vasconcelos, Juan Rulfo, Carlos Fuentes, etc. ${ }^{28}$

Quando o movimento surrealista chegou oficialmente ao fim em 1967, principalmente por motivo da morte de Breton, ele ganhou, por outro lado, uma nova notoriedade por coincidir com o descobrimento massivo do pensamento freudiano, que exaltava as liberdades oníricas. Paz colaborou muito, a partir daí, para a revitalização do movimento, ao produzir outros tantos ensaios e poemas surrealistas como Estrella de trés puntas: el surrealismo e Esto y esto y esto; rememorar sobre o papel fundamental do grupo, nas revistas que fundou - Plural (1971-1976) e Vuelta (1976-1998), e participar de programas de televisão com o intuito de difundir os significados do movimento.

O poeta chamou a atenção do "público-leitor" para a ideia de que os surrealistas não são importantes apenas artisticamente, mas também por compartilharem de uma profunda percepção ética e moral da sociedade, rara de encontrar no mundo contemporâneo. Certa vez, o poeta mencionou:

Minha adesão ao surrealismo foi por razões poéticas. E quando digo poéticas, digo morais. $\mathrm{E}$ isto, Buñuel dizia o mesmo. Para ele, o surrealismo foi uma escola moral, uma escola ética, de conduta. Para mim também. Em um grande momento que estávamos, por um lado frente a um mundo ocidental corrompido, atroz em tantos aspectos, por outro lado, os campos de concentração, o culto a Stalin, e tudo aquilo. Então, o surrealismo era um pouco como uma via de salvação e havia uma afirmação da poesia, da liberdade. ${ }^{29}$

O problema moral colocado por sua época e evidenciado pelo movimento surrealista estava relacionado, entre outros, aos limites existentes para a realização de uma sociedade mais justa e mais igualitária. Até que ponto o autoritarismo político ou o dinheiro ou a religião deveriam conduzir a imaginação e determinar a liberdade das pessoas para se atingir o objetivo da "boa sociedade"? Esta foi uma das grandes questões do movimento surrealista. Em um estudo recente do escritor mexicano González Torres sobre o poeta, o autor menciona, sem aprofundar na questão, o movimento surrealista como uma das manifestações modernas que mais influenciou Paz, ele mesmo dizia que: "[...] diante das promessas não cumpridas da revolução social, o poeta surrealista é a representação mais acabada de uma rebeldia arcaica, de uma faculdade visionária, que busca a restituição do humano na vida contemporânea." ${ }^{30}$ Mas que faculdade visionária era essa? O que havia sido perdido na sociedade contemporânea que os surrealistas foram capazes de resgatar? 
Talvez um determinado tipo de sensibilidade traduzida, pelos próprios surrealistas, como força moral capaz de rechaçar os valores convencionais relacionados à razão, à burguesia e à Igreja, e exaltar a paixão, a mistificação, o insulto, o riso maldoso e a atração. Uma moral, segundo Buñuel, transgressora, subversiva e que fazia sentido. Como afirmou o cineasta espanhol:

Com frequencia me perguntam o que foi o surrealismo. Não sei que desposta dar. As vezes digo que o surrealismo triunfou no acessório e fracassou o essencial. André Breton, Éluard e Aragon figuram entre os melhores escritores franceses do século XX, e estão em um bom lugar de todas as bibliotecas. Max Ernest, Magritte e Dalí se encontram entre os pintores mais caros e reconhecidos e estão num bom lugar de todos os museus. Reconhecimento artístico e êxito cultural que eram precisamente as coisas que menos importavam a maioria. O movimento surrealista o tinha sem o cuidado de entrar gloriosamente nos anales da literatura e da pintura. O que desejava mais que nada, desejo imperioso e irrealizável, era transformar o mundo e mudar a vida. ${ }^{31}$

Porém, no mundo tomado, cada vez mais, pelo capital, pela burguesia, pela publicidade, pela mídia e pelo espetáculo, ao ponto do próprio Breton ter considerado em 1955 a impossibilidade do escândalo como força de transformação social e se perguntar se publicar e divulgar ideias são uma forma de ação, ou uma maneira de dissolvê-la no anonimato da publicidade, a questão que se coloca a Paz seria: qual é, assim, a vigência do surrealismo? Ele a isso responde em entrevista ao crítico literário Carlos Monsiváis:

Eu não creio que o surrealismo nunca tenha tido vigência. A função do surrealismo, ao meu ver, é, não ser vigente. Ser a outra voz, a outra cara da sociedade. A voz secreta, subterrânea, a voz dissidente. O surrealismo é a enfermidade constitucional, a enfermidade congênita da civilização ocidental. Sua enfermidade sagrada. ${ }^{32}$

Essa "outra voz" incomoda, insubmissa, resistente, teimosa é a rebeldia necessária ao exercício da crítica moderna. Falar de rebeldia foi para Paz falar de liberdade. Aqueles que não são capazes de dizer não, segundo ele, estão mortos. A poesia é quando a rebelião se converte em revelação. De acordo com Monsiváis, essas duas palavras - rebelião e revelação - estremeceram Paz, mas a muitos não deram nem frio e nem calor. Elas são, para os surrealistas, manifestações marginais de uma mesma realidade que inicia, incita, provoca, 
transforma e maravilha o ser humano. A poesia moderna é, assim, uma tradição de rebeldia, na medida em que se mostrou insubmissa ao conformismo religioso e ao conformismo revolucionário da sociedade contemporânea. Por fim, vale apresentar aqui um trecho do poema de Paz sobre o surrealismo, publicado nos anos de 1950, em que a rebelião surrealista é revelada e reverenciada por meio de suas críticas sobre a necessidade de transformação da realidade política e social do ocidente.

Isto, isto e isto

O surrealismo tem sido a maça de fogo na árvore da síntese.

O surrealismo tem sido a camélia de cinza entre os peitos da adolescente possuída pelo espectro de Orestes.

O surrealismo tem sido o prato de lentilhas que o olhar do filho pródigo transforma em festim fumegante do rei canibal.

O surrealismo tem sido o balsamo de ferrabrás que apaga os sinais do balsamo original e o umbigo da linguagem.

O surrealismo tem sido a cusparada na hóstia e o cravo de dinamite no confessionário e o abra-te sésamo das caixas de segurança e das grades dos manicômios.

O surrealismo tem sido a chama ébria que guia os passos do sonâmbulo que caminha nas pontas dos pés sobre o fio de sombra que traça a folha da guilhotina no pescoço dos justiçados.

O surrealismo tem sido o prego ardente na fonte do geômetra e o vento forte que à meia noite levanta $o$ lençol das virgens.

O surrealismo tem sido o pão selvagem que paralisa o ventre da Companhia de Jesus até que a obriga a vomitar todos seus gatos e seus diabos encardcerados. O surrealismo tem sido um punhado de sal que dissolve as velhas moedinhas do realismo socialista.

O surrealismo tem sido a coroa de papelão do crítico sem cabeça e a víbora que desliza entre as pernas da mulher do crítico.

O surrealismo tem sido a lepra do Ocidente cristão 
Vasos comunicantes do moderno: Octavio Paz e o surrealismo

e o açoite de nove cordas que desenha o caminho de saída para outras terras e outras línguas e outras almas sobre o lombo do nacionalismo embrutecido e embrutecedor.

O surrealismo tem sido o discurso da criança soterrada em cada homem e a aspersão de sílabas de leite de leoa sobre os ossos calcinados de Giordano Bruno.

O surrealismo tem sido as botas de sete léguas dos escalpados das prisões da razão dialética e a tocha do purgatório que corta os nós da trepadeira venenosa que cobre os muros das revoluções petrificadas do século XX.

O surrealismo tem sido isto, isto e isto. ${ }^{33}$

\section{NOTAS}

I PAZ, Octavio. André Breton o la busca del comienzo. In: Excursiones/Incursiones: Dominio Extrangero. vol. 2. México: FCE, 2003. (|⿰ ${ }^{\mathrm{a}}$ ed. |99|).

2 Ver: BECERRA GRANDE, Eduardo. "Mariposa de Obsidiana": El surrealismo y la voz del mito. América sin nombre. (n. 9-10), Universidad de Alicante: España, noviembre 2007. p. 43-48. Disponível em: http://biblioteca.universia.net/html_bura/ficha/params/id/35527/07.html Acesso em: 10 fev. 2011 .

3 PAZ, Octavio. Conversaciones con Octavio Paz \& Álvaro Mutis - Sobre el surrealismo. México: Televisa. 1984. (Transcrição do programa televisivo).

4 PAZ, Octavio. El ocaso de la vanguardia: revolución, eros, metaironía. Revista Plural, México, n. 26, 1973, p. 4.

${ }^{5}$ La política no era nuestra única pasión. Tanto o más nos atraían la literatura, las artes y la filosofía. Para mí y para unos pocos entre mis amigos, la poesía se convirtió, ya que no en una religión pública, en un culto esotérico oscilante entre las catacumbas y el sótano de los conspiradores. Yo no encontraba oposición entre la poesía y la revolución: las dos eran facetas del mismo movimiento, dos alas de la misma pasión. Esta creencia me uniría más tarde a los surrealistas. PAZ, Octavio. Itinerario. México: FCE, 1993. p. 50. (nossa tradução).

6 PAZ, Octavio. Itinerário. México: Fondo de Cultura Económica, 1993. p. 51.

7 LÖWY, Michael. A estrela da manhã: Marxismo e Surrealismo. Rio de Janeiro: Civilização Brasileira, 2002. p. 16.

8 Conservé mis simpatias por el partido comunista hasta finales de los años cincuenta. Después, me fui alejando cada vez más de él. El fanatismo me repugna, donde quiera que lo encuentre. Todas las religiones han hallado la verdad. El marxismo, también. En los años treinta, por ejemplo, los doctrinarios marxistas no soportaban que se hablase del subconsciente, de las tendências psiclógicas profundas del individuo. Todo debía obedecer a los mecanismos socio-económicos, lo cual me 
Vasos comunicantes do moderno: Octavio Paz e o surrealismo

parecia absurdo. Se olvidaba a la mitad del hombre. BUÑUEL, Luis. Mi último suspiro. Espanha: Plaza \& Janés Editores, 2000. p. 194. (nossa tradução).

9 GRENIER, Yvon. Del arte a la política - Octavio Paz y la busca de la libertad. México: FCE, 2004. p. 69.

10 KRAUZE. Enrique. La Presidencia Imperial - Ascenso y caída del sistema político mexicano (19401996). México: Tusquets, 1997. p. 19.

" Era colaborador de un diário obrero de izquierda: El Popular, pero el pacto entre Stalin y Hitler me desconcertó y me dolió. Decidí separame del periódico y me alejé de mis amigos comunistas. Mis relaciones con ellos empeoraron a raíz del asesinato de Trotsky. (...) Yo me sentí cercado y acorralado. Entonces conocí a Victor Serge, a Benjamin Peret y a otros escritores revolucionarios desterrados en México. Esas nuevas amistades rompieron un poco mi aislamiento (...) Las conversaciones con los refugiados europeos, además, me revelaron mis limitaciones y mis lagunas. Aquellos amigos me descubrieron otros mundos. Y, sobre todo, lo que significa el pensamiento crítico. Como buen hispanoamericano yo conocía la rebelión; la indignación personal (no la crítica). A ellos les debo saber que la pasión ha de ser lúcida. In: PAZ, Octavio. Itinerário. México: Fondo de Cultura Económica, 1993. p. 35. (nossa tradução).

${ }^{12}$ Aprendí que la política no es sólo acción, sino participación. Tal vez, me dije, no se trata tanto de cambiar a los hombres como de acompañarlos y ser uno de ellos. In: PONIATOWSKA, Elena. Octavio Paz - Las palavras del árbol. Barcelona: Editora: Lumen, 1998. p. 35. (nossa tradução)

${ }^{13}$ Jorge Cuesta que fue muy amigo de Breton, fue el hombre que entendió mejor a Breton yo creo en México en aquella época. Cuesta me dijo Octavio usted debe ir a ver a Breton, le va a encantar, es un hombre muy inteligente, hay muchos puntos de contacto entre usted y él. Pero, yo me negué, lo vi de lejos. In: PAZ, Octavio. Conversaciones con Octavio Paz \& Álvaro Mutis - Sobre el surrealismo. México: Televisa, 1984. p. 148. (Transcrição do programa televisivo).

${ }_{14}$ Mis primeras dudas comenzaron en España por los métodos abominables que emplearon los comunistas para combatir a la oposición de izquierda, es decir, a los anarquistas, al POUM y a los trotskistas. Después, la disputa entre los estalinistas y los trotskistas me abrió los ojos sobre muchas cosas. Hice mías las críticas al trotskismo al estalinismo. Posteriormente, asumí las críticas al trotskismo de mucha gente que no era trotskista, como Victor Serge. Mi gran ruptura ocurrió al comenzar la década de los años cincuenta, cuando descubrí la existencia de campos de concentración en Unión Soviética. In: PERALTA, Bráulio. El poeta en su tierra: Diálogos con Octavio Paz. México: Hoja Casa Editorial, 1996. p. 165.

${ }^{15}$ PAZ, Octavio. André Breton o la busca del comienzo. In: Excursiones/Incursiones: Dominio Extrangero. vol. 2. México: FCE, 2003. p. 210. (|⿰⿱乛耳 ed. 1991).

${ }^{16}$ Cuando pienso en Aragon, Éluard, Neruda y otros famosos poetas y escritores stalinistas, siento el calosfría que me da la lectura de ciertos paisajes del infierno. Empezaron de buena fé, sin duda: Cómo cerrar los ojos ante los horrores del capitalismo y ante los desastres del imperialismo en Asia, y África y nuestra América? Experimentaron un impulso generoso de indignación ante el mal y de solidariedad con las víctimas. Pero insensiblemente, de compromiso en compromiso, se vieron envueltos en una malla de mentiras, falsedades, engaños y perjurios hasta que perdieron el alma. Se volvieron, literalmente, unos desalmados. Puedo parecer exagerado: Dante y sus castigos por unas opiniones políticas equivocadas? Y quién cree hoy en el alma? Agregaré que nuestras opiniones en esta materia no han sido menos errores o fallas en nuestra facultad de juzgar. Han sido un pecado, en el antiguo sentido religioso de la palabra: algo que afecta al ser entero. In: PAZ, Octavio. Apud. MONSIVÁIS, Carlos. Adonde yo soy tú somos nosotros. Octavio Paz: crónica de vida y obra. México: 
Vasos comunicantes do moderno: Octavio Paz e o surrealismo

RayaelAgua, 2000. p. 85.

17 Para los surrealistas hubo varios países de elección. En primer lugar, claro está, lo que llamaba Breton, las grandes lejanías, el Pacífico, Nueva Guinea, etc. Pero, sobretodo y de un modo especial, México. Fue uno de los países de elección de México. Y esto es muy antigo, Alvaro. Imagínete que... Bueno, tu lo sabes tambíen como yo, la primera prefiguración del mito mexicano en la poesia surrealista francesa es... está en un maestro de los surrealistas, que nunca fue realmente surrealista, fue su maestro Apollinaire. Apollinaire, en los poemas de Apollinaire hay una serie de alusiones a México. In: PAZ, Octavio. Conversaciones con Octavio Paz \& Álvaro Mutis - Sobre o surrealismo. México: Televisa, 1984. p. 142. (Transcrição do programa televisivo).

${ }^{18}$ Paz afirmou que conheceu o surrealismo "cuando ese fuego era brasa en algunos y en otros cenizas frias. No importa: me dio conciencia (...) Compreendí la función de la imaginación como fuerza de liberación del hombre. Creí que la poesía no podía ser sino una tentativa por realizar, aquí y ahora, en nuestras vidas y en la vida social, esa liberación." In: PAZ, Octavio. El pesadelo del regímen stalinista para mi generación. Revista Proceso, México, n. I 123, mayo de 1998, p. 10.

${ }^{19}$ La mayoría de aquellos revolucionários - al igual que los señoritos que yo frecuentaba en Madrid - eran de buena familia. Burgueses que se rebelaban contra la burguesía. Éste era mi caso. A ello se sumaba en mí cierto instinto negativo, destructor que siempre he sentido con más fuerza que toda tendencia creadora. Por ejemplo, siempre me ha parecido más atractiva la idea de incendiar un museo que la de abrir un centro cultural o fundar un hospital. In: BUÑUEL, Luis. Mi último suspiro. España: Plaza \& Janés Editores, 2000. p. 122.

${ }^{20}$ (Corset $=$ espartilho infame $=$ sufocante $)$.

${ }^{21}$ (tradução livre). Me cogieron suavemente y me depositaron en el átrio de la catedral. Me hice gris que muchos me confundieron con un montocito de polvo. Sí, yo misma, la madre del padernal, yo, encita del rayo, soy ahora la pluma que abandona el pájaro en el zarza. Bailaba, los pechos el alto y girando, girando, girando hasta quedarme quieta, entonces empezaba a echar hojas, flores y frutos. En mi vientre latía el águila. In: BECERRA GRANDE, Eduardo. "Mariposa de Obsidiana": El surrealismo y la voz del mito. América sin nombre. (n. 9- I0), Universidad de Alicante: España, noviembre 2007, p. 43-48. Disponível em: http://biblioteca.universia.net/html_bura/ficha/params/ id/35527 I07.html Acesso em: 10 fev. 201 l.

${ }^{22}$ STATON, Anthony. Correspondencia: Octavio Paz/Alfonso Reyes (1939- 1959). México: FCE, 1998. p. 29; 150.

${ }^{23}$ Em carta a Arnaldo Orfila, no dia 5 de abril de 1968, Paz afirmou sobre o nacionalismo: "Nuevo e hispanoamericano significa, ante todo, hablar un español de americanos del siglo $X X$. No carecemos en la trampa del nacionalismo. Somos cosmopolitas por totalidad, por nacimiento: somos de este tiempo. Pero nuestro cosmopolitismo, a diferencia de los modernistas, no es fuga hacia Babilonia, Roma, París, Moscú o Nueva York. In: PAZ, Octavio. Cartas cruzadas Octavio Paz y Arnaldo Orfila Reynal (1965-1970). México: Siglo XXI, 2005. p. 156.

${ }^{24}$ El nacionalismo fue una invención europea y el cosmopolitismo también; es decir, la dos son actitudes que reflejan lo que pasa en otros lados. Lo importante es ni extasiarse ante el "Mexiquitito"ni tampoco escupir contra él. Lo importante es escribir obras que, por lo menos, sean válidas en la lengua española en este momento. Por lo menos! Y si bien nos va, que sean realmente universales. Pero para crear obras universales no es indispensable seguir el último grito de París o de Londres. In: PONIATOWSKA, Elena, Octavio Paz - Las palavras del árbol. Barcelona: Editora Lumen, 1998. p. 96. (nossa tradução).

${ }^{25}$ Todo cambió después del festival de Cannes em que el poeta Octavio Paz - hombre del que 
Vasos comunicantes do moderno: Octavio Paz e o surrealismo

Breton me habló por primera vez a quien admiro desde hace mucho - distribuía personalmente a la puerta de la sala un artículo que había escrito, el mejor, sin duda, que he leído, un artículo bellísimo. La película conoció un gran éxito, obtuvo críticas maravillosas y recebió el Premio de Dirección. (...) Tras el éxito europeo, me vi absuelto del lado mexicano. Cesaron los insultos, y la película se reestrenó en una buena sala de México, dónde permaneció dos meses. In: BUÑUEL, Luis. Mi último suspiro. España: Plaza \& Janés Editores, 2000. p. 237.

26 PAZ, Octavio. Jardines Errantes Cartas de Octavio Paz ao poeta e crítico francês J. C Lambert 1952-1992. México: Seix Barral, 2008. p. 73.

${ }^{27}$ A propósito da exposição El arte del Surrealismo, a Revista Plural publicou a carta de Octavio Paz a Fernando Gamboa. In: PAZ, Octavio. El arte del Surrealismo. Revista Plural, México, 1972. p. 36.

28 PONIATOWSKA, Elena. Octavio Paz - Las palavras del árbol. Barcelona: Editora Lumen, 1998. p. 18.

29 MONSIVÁIS, Carlos. Adónde yo soy tu somos nosotros. Octavio Paz: crónica de vida y obra. México: RayaelAgua, 2000. p. 160.

${ }^{30}$ GONZÁLEZ TORRES, Armando. Las guerras culturales de Octavio Paz. México: Colibrí, 2002. p. 25.

${ }^{31}$ A menudo me preguntan qué há sido del surrealismo. No sé que respuesta dar. A veces digo que el surrealismo triunfó en lo accesorio y fracasó en lo esencial. André Breton, Éluard y Aragon figuran entre los mejores escritores franceses del siglo $X X$, y están en buen lugar de todas las bibliotecas. Max Ernest, Magritte y Dalí se encuentran entre los pintores más caros y reconocidos y están en buen lugar en todos los museos. Reconocimiento artístico y éxito cultural que eran precisamente las cosas que menos nos importaban a la mayoría. Al movimiento surrealista le tenía sin cuidado entrar gloriosamente en los anales de la literatura y pintura. Lo que deseaba más que nada, deseo imperioso e irrealizable, era transformar o mundo e cambiar la vida. In: BUÑUEL, Luis. Mi último suspiro. Espanha: Plaza \& Janés Editores, 2000. p. | 40. (nossa tradução).

32 MONSIVÁIS, Carlos. Adonde yo soy tú somos nosotros. Octavio Paz: crónica de vida y obra. México: RayaelAgua, 2000. p. 121.

33 PAZ, Octavio. Esto y esto y esto. Tradução de Antônio Moura. Disponível em: http://www. lunaeamigos.com.br/aconteceu/aconteceu70.htm Acesso em: I 0 fev. 201 I. Ver poesia no original: PAZ, Octavio. "Esto y esto y esto". In: Obra Poética II (1969-1998). vol. 12, México: FCE, 2004. p. II9. (I ${ }^{\mathrm{a}}$ ed. 2003).

Artigo recebido em junho de 20 I I. Aceito em agosto de 201 I. 